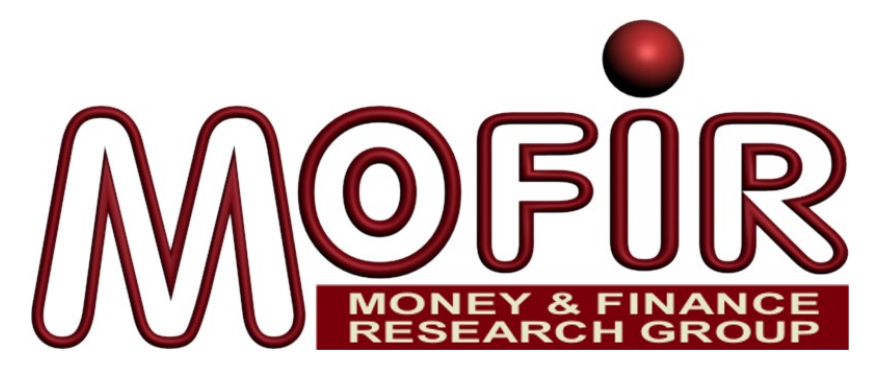

\title{
Market Opportunities and the Owner Identity. Are Family Firms Different?
}

Marco Cucculelli

Università Politecnica delle Marche, Department of Management and Industrial Organization MoFiR

Francesco Marchionne

Università Politecnica delle Marche, Department of Economics $M o F_{I} R$

MoFiR working paper $n^{\circ} 32$

October 2009 


\title{
Market Opportunities and the Owner Identity. Are Family Firms different?
}

\author{
Marco Cucculelli ${ }^{\text {a }}$ \\ Marche P. University
}

\author{
Francesco Marchionne ${ }^{\mathrm{b}}$ \\ Marche P. University
}

\begin{abstract}
We test the hypothesis that the identity of the owner affects firm ability to seize market opportunities differently according to the firm's actual vs. "optimal" size (size gap). By grouping firms in size clusters having a similar probability of adopting a size-adjusting strategy (growth or downsizing), we measure how the sensitivity of firm sales to demand shocks changes in response to the difference in owner identity and the firm size gap. We use data from a panel of 7,459 continental western European firms over the period 1995-2004 and Eurostat 3-digit sectoral data on firm size distribution in Europe. Our findings show that family business sales are less sensitive to market demand than other firms, particularly when the actual firm size is larger than optimal size.
\end{abstract}

Key Words: family firms, owner identity, performance, optimal size class.

JEL Classification: G32, D21, L11, L25, L26.

\footnotetext{
a Corresponding author, Faculty of Economics "Giorgio Fuà" - Marche P. University, Piazzale Martelli, 8 - 60100 Ancona, Italy - Phone: +39-071-2207162 - Fax: +39-071-2207199, m.cucculelli@univpm.it

b Faculty of Economics “Giorgio Fuà” - Marche P. University, Piazzale Martelli, 8 - 60100 Ancona, Italy

- Phone: +39-338-7128276 - Fax: +39-071-2207199, f.marchionne@univpm.it
} 


\section{Introduction}

The traditional perspective on firm growth is that firms are attracted to some sort of "efficient size" as a result of a forward-looking process in which firms adjust their current scale of production to anticipate future market trends. Once firms have reached that size, they are assumed to slow down their growth or to grow no further. When the firm size is larger than optimum, firms are forced to downsize in order to re-gain operating efficiency or recover flexibility in operations. Vast empirical literature provides evidence to support these predictions (see Cabral and Mata, 2003; Stavrou et al., 2007; Angelini and Generale, 2008)

Size-oriented strategies targeted at approaching an efficient scale of output are inherently risky because they require exploring new market opportunities, changing established routines or even reshaping the company's organizational structure. As such, they require a particular risk attitude in the decision maker.

Agency theory stresses that the extent of involvement in risky activities is likely to be influenced by the ownership of the firm (Jensen and Meckling, 1976; Fama, 1980). Most past studies have tended to define ownership structure primarily in terms of ownership concentration or managerial ownership, thus overlooking the impact of owner identity. In recent years, a growing body of literature has emphasized the owner identity - in addition to the ownership concentration - as a crucial dimension for understanding the company strategy, as it affects the risk preferences of the decision maker and the congruence of goals between principals and agents (Faccio and Lang, 2002). Within this large empirical literature, a special attention has been devoted to the family ownership (Bertrand and Shoar, 2006; Villalonga and Amit, 2006; George et al., 2005; Pedersen and Thomsen, 2003). Family firms might be in general more risk averse than other firms since typically a higher share of the owner's wealth is invested in its firm; hence their behaviour may be affected by a large sensitivity to uncertainty and by a risk attitude which may induce them to avoid decisions that may affect the firm's survival or the stability of control. These effects may be larger, the more risky is the required size-adjusting strategy.

We explore this issue by studying how the owner identity affects the ability of the company to seize market opportunities when there is a difference between the actual 
firm size and its "efficient" size (size gap). We analyse the company response to industry demand shocks for three groups of owners, i.e. families (that also include individuals), industrial owners and financial owners. The remaining group of identities ${ }^{1}$ is the baseline for the empirical analysis. We focus on family firms as a vast recent literature (Miller et al., 2007; Bertrand and Shoar, 2006; Maury, 2006; Pedersen and Thomsen, 2003) provides evidence on the very peculiar impact of their risk-taking behaviour. Our main concern for family owners arises from their "risk-avoidance behaviour", which is spurred by the existence of growth opportunities that expire after the founder's tenure (Almeida e Brito and John, 2001) and that create a long-term commitment to the survival of the company (Bertrand and Shoar, 2006; Villalonga and Amit, 2006).

Our research strategy consists of three main stages. First, we identify the optimal size class for each country/industry pair through the survivor technique, originally introduced by Stigler (1958) and developed by Giordano (2003). The choice to identify a different efficient class for each country/industry pair reflects the findings of Geroski and Gugler (2001), which reject the hypothesis of convergence in corporate sizes across European countries. Second, we allocate each firm of the sample to either the optimal or the sub-optimal (larger and smaller) size class defined for each country/industry pair. Third, we estimate the sensitivity of the firm's sales to demand shocks by owner status (families, industrial and financial owners) within each size class in order to trace out systematic deviations in firm behaviour due to the nature of the owner.

In order to compare how different owners face similar market opportunities, we group firms in different size clusters having a similar probability of adopting a sizeadjusting strategy. Therefore, we use the concept of optimal size class as a device to provide an objective benchmark for comparison of firm behaviour, not to define the optimal size class in the industry. The choice of the survivor technique for the identification of the optimal size class aims to make the comparison of firm behaviour by size more informative than the econometric approach of controlling for size and industry. By grouping companies in size clusters having a similar probability of adopting a size-adjusting strategy, it allows to relate the adoption of such strategies to differences in the owners' attitude towards growth or downsizing. Despite a number of

\footnotetext{
${ }^{1}$ The residual group of owners includes: Foundation, Employees/Managers, Insurance companies, Mutual and Pension Funds, Funds/Trust, Self-owned and Other unnamed shareholders (See appendix).
} 
approaches for estimating the efficient scale have been introduced in the literature (see Audretsch et al., 2001; Goddard et al., 2005), here we follow the tradition in the industrial organisation literature and adopt the method which was first introduced by Stigler (1958). As our results may be somewhat sensitive to the definition and the selection of the optimal size class, we run a large number of robustness tests concerning the identification of the optimal size class.

Our findings show that the identity of the owner affects company performance differently according to the size gap, i.e. the difference between the actual and the optimal size of the single company. When firms are smaller or larger than the optimal size, family ownership hinders the company's ability to seize market opportunities more than industrial or financial ownership. Our explanation for this behaviour recognizes the particularity of family ownership with respect to other firms, both in terms of trade-off between firm growth and control, and the conservatism induced by the deterioration of the "stewardship" perspective (Miller et al., 2008). As market strategies targeted to reduce the size gap are inherently risky, differences in the sensitivity of firm performance to market demand reveal differences in the risk attitude of the decision makers and, accordingly, in their entrepreneurial orientation (Miller, 1983; Zahra, 2005).

The paper is organised as follows. Section 2 presents the empirical model. We first discuss the empirical equation and then the survivor technique. Section 3 is devoted to data sources, descriptive statistics and preliminary tests. Findings are analyzed in Section 4. Section 5 reports results from a robustness analysis. Conclusions are drawnup in the last section.

\section{The empirical model.}

\subsection{Estimated equation}

Revenue-oriented strategies are inherently risky and require a particular risk attitude in the decision maker (entrepreneur). The skills required to manage the revenue side of a firm's operations (sales) are not different from those needed to start a new business. Firms must create new products and find new markets in which they can be sold: discovering an area of a firm's comparative advantage calls for much more 
innovation and involves greater uncertainty than simply running a business, especially when the firm faces new environments in highly competitive export markets. This is more likely to occur in a period of rapid demand change, when a firm's sales depend on its ability to accommodate the largely unpredictable decisions of potential customers and consumers (Frydman et al., 1998; Grosfeld and Roland, 1996).

We use the sensitivity of firm sales to demand shocks as a measure of the ability of the firm to seize market opportunities. Sales sensitivity to demand shocks is used to measure the extent to which the owners' attitude toward risk affects the company's willingness to take actions that aim to change the status quo (Gomez Meja et al., 2007). A low (high) sensitivity to demand shocks should signal the preference to take decisions that are more (less) conservative than needed in a particular market environment, thus implying a risk-avoiding behaviour by the company in its strategic choices.

We derive our model from Bertrand, Metha and Mullainathan (2002) and Sraer and Thesmar (2007). Bertrand et al. (2002) use variation in mean industry performance as a source of profit shocks in the single firm in order to trace the propagation of shocks through a business group. Sraer and Thesmar (2007) estimate a fixed effect model, where single firm sensitivity is identified by the correlation between the changes in log sales and log employment. In both the models, industry shocks provide an ideal candidate to measure firm sensitivity since they affect individual firms but are - to a large extent - beyond the control of individual firms.

In our estimations, we use firm annual sales as the dependent variable, whereas the Eurostat Annual Turnover Index (henceforth referred to as ATI) is the independent variable. The latter is a specific business cycle indicator used as a proxy for the sectoral industry demand. It captures the evolution of the market of goods and services in the industrial sector $k$ through turnover changes over time. The empirical specification is as follows:

$S A L E S_{, k, t}=\beta \cdot\left(A T I_{k, t}\right)+\beta_{s} \cdot\left(C_{s, i} \cdot A T I_{k, t}\right)+\beta_{s, r} \cdot\left(C_{s, i} \cdot O_{r, i} \cdot A T I_{k, t}\right)+\delta_{q} \cdot\left(Z_{q, i, t-1}\right)+u_{i, k, t}$

where SALES is the turnover of firm $i$ in sector $k$ at time $t$ and ATI is the Eurostat Annual Turnover Index of sector $k$ at time $t$. All continuous variables are in logs. The error term is modelled with $u_{i, k, t}=\alpha_{i}+\mu_{t}+\varepsilon_{i, k, t}$, where $\alpha_{i}$ is an individual specific 
random effect at firm level, $\mu_{t}$ is the year dummy and $\varepsilon_{i, k, t}$ is the idiosyncratic error. $C_{s}$ indicates the size class gap. The optimal size class $C_{0}$ - identified by the survivor analysis (see next paragraph) - is the baseline in estimates. Consequently, $C_{-1, i}$ is a dummy that assumes 1 when firm $i$ is in the smaller-than-optimal size class, whereas $C_{+1, i}=1$ when firm $i$ is of larger-than-optimal size and zero otherwise. Henceforth, we indicate the smaller-than-optimal size class with $C_{-1}$ and the larger-than-optimal size class with $C_{+1} . O_{r}$ are dummies related to the ownership. $\mathrm{O}_{1}, \mathrm{O}_{2}$, and $\mathrm{O}_{3}$ assume the value 1 when the firm $i$ is a family business, an industrial company, or a financial company, respectively, and 0 otherwise. ${ }^{2} Z_{q}$ is a set of controls that are common to all owner statuses and efficient size classes (homogeneous controls). They are the number of employees $(\log )$, the firm age $(\log )$, and a diversification variable (the number of market segments in addition to the main business). Control variables are lagged at time $t-1$ to avoid problems of causality and simultaneity with the dependent variable.

As we exclude larger firms in order to limit the potential bias due to their market power, we assume that other firms strive to follow market demand, but fail to do so perfectly because they face constraints and limitations of some sort (managerial, financial, entrepreneurial, etc). Thus, $0<\beta<1$ in equation (1). With regard to the size class distribution, we expect that the ability to follow market demand would be maximised in the optimal size classes. Therefore, we expect $\beta_{-1}<0$ and $\beta_{+1}<0$ in equation (1). As concerns controls, we expect a positive impact of size and age, whereas the contribution of the diversification variable is expected to be negative because of the risk-revenue trade-off.

Our main hypothesis is that ownership affects the sensitivity of firm sales to demand shocks according to the owner identity. In particular, we hypothesise a lower ability of family-owned firms to seize market opportunities in comparison to others. Family firms in $C_{-1}$ may show lower sensitivity as a result of a trade-off between firm growth and control, and some potential managerial and financial constraints. Family firms in larger-than-optimal classes may suffer inertia more than other firms, thus reducing their ability to follow market demand. In sum, we expect lower sensitivity of family firms with respect to other firms, i.e. $\beta_{-1, r=1}<0$ and $\beta_{+1, r=1}<0$ in equation (1).

\footnotetext{
2 The remaining owner types are the baseline for the estimates: employees-managers, foundations, insurance companies, mutual and pension funds, and self-owned/cooperatives.
} 
In contrast, industrial and financial companies may show higher sensitivity of sales to ATI than other firms because of economies of scale, i.e. $\beta_{s= \pm 1, r=2}>0$ and $\beta_{s= \pm 1, r=3}>0$.

A large empirical literature provides motivations for this expected result. A "risk-avoidance behaviour" may arise in family firms as a result of the large proportion of the owner's wealth invested in the business. This makes these firms risk-adverse (Demsetz and Lehn, 1985; Villalonga and Amit, 2006) and keen to avoid risky business decisions that may endanger firm survival (Gomez Mejia et al., 2007). In general, "satisficing" (Sargant, 1934) rather than maximizing policies (Simon, 1959; Baumol, 1959) may explain the low growth of owner-managed companies and family firms that exchange sales growth with control amenities or other agency benefits. In addition, a larger likelihood that the firm's goal might change over the firm life cycle is present in family firms in response to both the conflicts between principals and their agents (Mueller, 1972) or an intergenerational negative drift which involves heirs' risk aversion or talent (Sonfield and Lussier, 2002). Moreover, the willingness to engage in strategic change activities - such as downsizing and restructuring - can be low in family firms if the unwillingness to change strategy arises from a family management becoming progressively insulated from environmental changes and failing to perceive and react to critical environmental changes (Goodstein and Boeker, 1991; Stavrou et al, 2007; Bergh and Ngah-Kiing Lim, 2008). Contrarily, financial and industrial owners are more likely to undertake ambitious investment programs to exploit economies of scale and are less likely to pursue niche strategies related to flexibility or product differentiation (Thomsen and Pedersen, 2000). Furthermore, these companies are usually managed by professionals for whom the maximization of sale growth rate is often a major goal and that follow a strict profit maximizing behaviour in order to fulfil the shareholders' expectations.

As the organisational inertia or heirs' risk aversion could impact the effectiveness of family management over time, we consider the impact of the age on firm behaviour by splitting the sample by firm age (Villalonga and Amit, 2006; Bertrand and Shoar, 2006). We assume that founder-run businesses are within the subsample of young firms (firms with less than 25 years), whereas heir-run businesses belong to the subsample of mature firms (firms older than 40 years). In accordance with Miller et al. (2007), we do not expect significant difference between family and other 
owners in the former subsample (younger firms), but a negative effect for family businesses in the latter (older firms). However, as control variables could differently affect firm performance according to the size gap, we also allow for a different sensitivity to market demand in the optimal size class by running the model by size class subsamples. In this way, we exploit the heterogeneity of control variables through subsamples in order to have a finer control over the size class distribution. We will refer to this procedure as the heterogeneous controls method. ${ }^{3}$ As this approach allows for different demand elasticity through ownership in the optimal size class, we expect to get better results also when the firm distribution is skewed or outliers are present.

\subsection{Survivor analysis}

We use the survivor technique to identify the optimal size class at industry level. The strategy of this technique is to "classify the firm in an industry by size, and calculate the share of industry output coming from each class over time. If the share of a given class falls, it is relatively inefficient, and in general is more inefficient the more rapidly the share falls" (Stigler 1958, p.56).

Giordano (2003) proposes two chi-squared tests to check the empirical usability of this technique. The first test $\left(\chi_{A}^{2}\right)$ verifies that market share shifts across size classes over time exceeding random fluctuations. Null hypothesis is the invariance of distribution over time. The theoretical (or expected) frequencies in the final year, $E_{k, T}$, are the initial year class shares in percentage, $S_{k, t}$, multiplied by the final year total market size, $Q_{T}$, that is $E_{k, T}=S_{k, t} \cdot Q_{T}$. The goodness-of-fit between the observed distribution $O$ and expected distributions $E$ in the final year is tested as follows:

$$
\chi_{A}^{2}=\sum_{k=1}^{K}\left[\frac{\left(O_{k, T}-E_{k, T}\right)^{2}}{E_{k, T}}\right]
$$

\footnotetext{
3 Smaller firms can improve performance by hiring a professional manager, especially if he replaces a family manager (Bertrand and Schoar, 2003). Larger firms can exploit scale economies and size related market power (Serrasqueiro and Macas Nunes, 2008). Conversely, financial constraints due to information asymmetries could limit investments in smaller firms and thereby hinder their ability to grow, whereas increasing size can intensify formality among agents in large firms, thus reducing the owner's control on manager (Serrasqueiro and Macas Nunes, 2008).
} 
where $K$ is the number of size classes. The $\chi_{A}^{2}$ test has $K-1$ degrees of freedom since once the total of the expected frequencies is fixed, $K-1$ of the $K$ observed frequencies can be freely assigned to any of the $K$ size classes, and the $K^{\text {th }}$ is automatically assigned. If the $\chi_{A}^{2}$ computed value is greater than the critical value, null hypothesis is rejected and the observed shift in distribution is statistically significant at the stated level of confidence and vice versa. We note that the levels of confidence are reversed with respect to the standard levels (e.g. 95\%) since $\chi_{A}^{2}$ is actually used to test the alternative hypothesis of distribution variability over time. We, therefore, accept the null hypothesis only for low levels of confidence (e.g. 5\%).

The second test $\left(\chi_{B}^{2}\right)$ aims to determine whether the optimal size class also has a significant change of market share within shifts of the overall distribution. If it has undergone a not statistically significant shift over time, then it would be incorrect to conclude that an optimal size class exists. The null hypothesis is the invariance of optimal size class market share. We compute $\chi_{B}^{2}$ as follows:

$$
\chi_{B}^{2}=\left[\frac{\left(O_{k, T}-E_{k, T}\right)^{2}}{E_{k, T}}\right]+\left[\frac{\left(O_{z, T}-E_{z, T}\right)^{2}}{E_{z, T}}\right]
$$

where $O_{z, T}$ and $E_{z, T}$ are the sum of the observed and the expected share of all suboptimal classes in the final year, respectively. The $\chi_{B}^{2}$ test has only 1 degree of freedom because all size classes other than the optimal are added together and treated as a single class; so $K=2$ and $K-1=1$. The null hypothesis that the market share of the optimal size class is the same in both the initial and final year is rejected at a high level of confidence (e.g. 95\%). The $\chi_{B}^{2}$ test is a sufficient condition, whereas the $\chi_{A}^{2}$ test is a necessary one. In both the formulations, the sum of the observed frequencies will always equal the sum of the expected frequencies as the $\chi^{2}$ test requires. Note that this procedure also considers the impact of market growth.

Even if the differences in the demand and supply conditions in the industry structure across European countries have progressively vanished in the last decades, there are a number of reasons - related to the definition of the optimal scale - that lead 
us to use a definition of optimal size at country level (Geroski and Gugler, 2001). First, the literature on finance and growth shows that country-specific effects exist and hurt the firm growth differently according to the country-specific institutional and normative framework (Demirguc-Kunt and Maksimovic, 1998). Second, not all countries are at the technological or managerial frontier, and large variation in relative factor input prices can be expected (Audretsch, 1995). Third, a different efficient scale at country level may arise as a result of differences in the degree of industry integration and in the level of the manufacturing process within the vertical industry chain (Audretsch and Yamawaki, 1992). Fourth, the characteristics of each single industry (for example, industries producing goods to the final consumer vs goods used as intermediate inputs), as well as the industry capital intensity may affect the identification of the industry optimal scale (the minimum efficient scale tends to be understated in a highly capitalintensive industry and overstated in industries where the capital-labour ratio is relatively low) (Audretsch, 1995; Audretsch et al., 2001). Fifth, differences in the country composition of activities within the same three-digit industry code (e.g. part and components vs assembly in automotive), or the type of vertical contractual relationship between firms (e.g. hierarchical vs districtual- or market-relationship) may also affect the extent of the optimal firm size in each industry (the larger the contractual relationship, the lower the vertical integration of the industry and the lower the minimum efficient scale computed at country level) (Audretsch et al., 2001). ${ }^{4}$ In the robustness section, we test for the inclusion of a country dummy in the empirical model. Estimated results do not show significant differences, thus sustaining our choice to use a definition of optimal size class at country level.

\section{Data}

\subsection{Data source}

4 The persistence of sub-optimal plants and firms in industrial markets (Audretsch, 1995; Audretsch and Yamawaki, 1992) depends on a number of compensating factors that make them grow and approach an efficient scale of output to remain viable in the long run (Audretsch, 1991). However, in the short run, they incur the risk whether or not they possess the right endowment or qualities in terms of the product offered and the management to facilitate growth and survival. As such, they require a particular risk attitude in the decision makers in order to manage both the ordinary tasks and the growth options. 
We combine three different data sources to identify the optimal size class, to describe the market demand and to assess firm performance.

A) Optimal size class and survivor technique. We use the European Business Database on Industry, Trade and Services (henceforth referred to as EBD) to identify the optimal size class. EBD is an aggregated dataset - provided by Eurostat - collecting information on economic variables (sales, employment, operating profits, entry and exit of firms) by sector broken down by size classes. It consists of 15,790 observations covering 103 sectors (3 digits NACE Rev. 1) and 16 Western European countries over the period 1995-2004. We use EBD data for the survivor technique. According to Stigler's (1958) original approach, we identify the optimal size class in each sector by taking the employment size class with the largest increase in aggregate turnover over the period (Turnover Classification, henceforth referred to as TOC). We also identified the optimal class by using other different grouping variables: the Operating Surplus (OSC), since family businesses may not grow as much as other firms even when their profitability is similar (Miller et al., 2007); the share of firm population (henceforth referred to as NEC), as in Blair and Vogel (1978); the share of employment (henceforth referred to as EMC), as in Balloni and Cucculelli (1998).

B) Industry demand. Sectoral demand is proxied by the Eurostat Annual Turnover Index, ATI, which indicates industry sales for EU15 in nominal terms. It is a business cycle indicator that shows the evolution of the market of goods and services in industrial sectors. The Index breakdown by industry provides a very close link between the demand trend at European level and single company sales. The fine-grained industry breakdown at 103 sectors chosen in our analysis arises from the limitation indicated by Sraer and Thesmar (2007) on aggregate industry data. When the industry classification is too basic to account for the firm's relevant market, the estimated sensitivity parameters may have a substantial downward bias, rather similar to a measurement error and with very modest explanatory power. We avoid this restriction by using the threedigit NACE industry classification.

C) Firm performance data. Firm level data for 7,459 firms is provided by Analyse Major Database from European Sources (AMADEUS). Our dataset consists of 96,890 observations at firm level from 26 European countries over the period 1995-2004. The company accounting statements are harmonized by Bureau Van Dijk, thus making the 
cross country comparison reliable. This dataset is biased against the smallest companies because it includes top 1 million companies which have at least 10 employees. However, we cut away all firms with less than 20 employees since the high entry/exit rate of small firms in this size class yields skewed firm size distribution (Cabral and Mata, 2003) that, in turn, could generate a sample selection problem. We have also eliminated firms with more than 2,000 employees because of their potential market power. From AMADEUS, we derive data on firm sales, the owner status, the number of employees, the firm age, and a diversification variable at firm level made up by the number of four-digit sectors in which each firms operate. Owner status is identified through the ultimate owner identification procedure adopted by AMADEUS (see Appendix for details).

\subsection{Descriptive Statistics}

We are able to associate the demand index ATI to 94.6 percent of total firms, thereby obtaining a good match between EBD and AMADEUS. Table 1a presents descriptive statistics of the total sample in 2004 broken down by owner status. Family firms are younger and smaller with respect to industrial and financial owners and they are slightly more diversified than other owners with 2.8 sectors compared to the overall 2.64. As $A T I$ is similar in mean, standard deviation and median through owner status, distribution of family businesses among sectors cannot explain the observed differences in size parameters. Table $1 \mathrm{~b}$ focuses on firm growth rate by ownership. Consistently with the large empirical literature on firm growth, younger firms grow more than larger ones, and when the ownership types are taken into account, family businesses in the aggregate outperform all other owners in terms of sale growth rate.

Table 2 reports descriptive statistics at firm level broken down by size class. Using TOC to select the optimal size class, firms in $C_{-1}$ are on average younger (37 vs. 40 years) and more diversified (2.8 vs. 2.6 sectors) than firms in the optimal size class; conversely, firms in $C_{+1}$ are neither older nor more diversified. We obtain similar results using the OSC, except for the lower level of sales and employees in $C_{+1}$. This suggests that firms are more similar with regard to profits rather than sales. As similar results arise from the survival technique using $\mathrm{NEC}$ and EMC, in the following empirical analysis we will concentrate on TOC and OSC. 
We validate the survivor technique by running the $\chi^{2}$ tests for all available sectors in each country. Table 3 shows the distribution of the results for all the $\chi_{A}^{2}$ and $\chi_{B}^{2}$ tests by classification methods. As we perform a separate test for each countrysector pair, we have altogether 1182 (974) tests using TOC (OSC). We report only the number of test rejections and its percent on total number of tests run. At 10 percent confidence, the null hypothesis of $\chi_{A}^{2}$ test (same distribution of size class shares) is rejected in all sectors using both TOC and OSC. At 5 percent, the null hypothesis of $\chi_{B}^{2}$ test (same share of optimal size class) is rejected only in 0.89 percent of sectors when the TOC is used and only in 0.43 percent of sectors for OSC. The two $\chi^{2}$ tests show that the survivor technique is appropriate to our dataset and provides reliable information to identify optimal size class. ${ }^{5}$

Table 4 shows the joint (conditional) distribution by efficient size class and ownership for both TOC and OSC. Using TOC, the number of family firms in the smaller size class $(45.75 \%)$ is higher than industrial companies $(41.40 \%)$ and financial companies (37.04\%). Figure 1 provides the incidence of the relative share of each owner type by size class. OSC yields a slightly different result. We find a very large share of financial companies in the optimal size class together with a higher number of firms in larger size classes. These results suggest that ownership may affect firm growth but not firm performance, as in Hamelin and Trojman (2007) and Miller et al. (2007). Thereby, we test our hypothesis using both the classifications.

\section{Findings}

Tables $5 \mathrm{a}$ and $5 \mathrm{~b}$ present results from the estimates from the TOC-and OSC-derived size classes identification. We use a random effects model because it is appropriate for microeconomic panel data such as our sample (Greene, 1993; Verbeek, 2000). We also use a cluster correction at firm level to reduce potential serial correlation and robust standard errors to correct potential heteroscedasticity. Control variables are on average statistically significant and present expected signs (Table 5a and 5b). In particular, EMPLOYEES and AGE affect positively next year's sales (e.g. respectively 0.188 and

\footnotetext{
${ }^{5}$ We have omitted detailed results of the tests to save space, but they are available from the authors on request.
} 
0.121 in the Baseline specification), whereas the DIVERSIFICATION coefficient is negative in the Baseline and Ownership specification and not significant elsewhere. ${ }^{6}$

The sensitivity of sales to ATI is significant and has the expected positive sign. It is also smaller than 1 according to the model. In column Ownership, the sensitivity to sectoral demand shocks interacted with the ownership variable is negative for family businesses $(-0.0725)$ and positive for industrial and financial companies (0.0134 and 0.0184). It indicates that family firms' ability to seize the market opportunity is lower than other firms, particularly with respect to industrial and financial companies.

Moving on to the Efficient Size Class column, the inclusion of the efficient size class dummy reduces the number of observations from 44,523 to 22,204 , but allows to explain a larger portion of sales variance $\left(\mathrm{R}^{2}\right.$ rises up from 0.238 to 0.338$)$. Firms smaller (larger) than optimal size have a low (high) sensitivity of -0.0234 (0.0398) to ATI when the optimal class is identified by firm turnover. We find similar results for the other classification variables used in the analysis.

We check the joint effect of efficient size classes and ownership in the last columns of Table 5a (see Interactive). The estimated sensitivity of sales is lower for family firms than other firms when they are outside the optimal size class, thus producing an inverted U-shaped curve for family firms (Interactive-All). The coefficients are 0.0120 and 0.0286 respectively for firms smaller and larger than the optimal size. Moreover, family businesses show larger negative coefficient when they are larger than the optimal size, whereas the impact is reduced when they are smaller. As this is the case for all the classification variables used in the survivor technique, we think that some type of strategic inertia may affect firm performance in large family firms. Conversely, the sensitivity of sales to demand shocks for industrial and financial companies is higher when they are larger than the optimal size, thus allowing for a greater ability of professional managers to seize market opportunities.

To further analyse the potential impact of inertia on business performance, we draw on the literature on the firm age-performance relationship (Miller et al., 2008). As the risk-aversion of family management is expected to vary through age, we compare young and old firms assuming that founders drive young family firms and heirs the old ones. We address this issue in columns 5 and 6 of Table 5 a. On one hand, the difference

\footnotetext{
${ }^{6}$ We report Baseline and Ownership estimations from Table 5a in Table 5b to facilitate the comparison of results.
} 
between family and other owners is not statistically significant when the firm's age is less than 25 years. Moreover, the negative performance of young family firms tends to decrease in relation to other firms. On the other hand, family firms older than 40 years show the lowest sensitivity to market demand. In this case, we also have large differences between size classes. These findings are consistent with the hypothesis that heir-managed firms are less keen to seize market opportunities. In summary, family owners show a sensitivity of sales to demand shocks, which is lower than that of other owners. The results are likely to be driven by heir-run family businesses, whereas founder-run businesses do not behave differently from other firms (Villalonga and Amit, 2006; Miller et al. 2007).

Table $5 \mathrm{~b}$ reports estimated results when the OSC is used to identify the optimal size class. Again, the sensitivity to market demand is lower for family owners than other owners in $C_{-1}$ and $C_{+1}$ (-0.0120 and -0.0286 , respectively). Similarly, the last two columns of Table $5 \mathrm{~b}$ show that heir-run businesses - and not founder-run ones - drive the results. Moreover, we find that the negative effect for family firms in $C_{+1}$ is stronger than that in the case of the TOC, i.e. the underperformance of family firms appears to be large when the optimal size class is identified by a pure profit maximisation rule.

In order to relax the assumption of common controls in equation (1) by allowing for heterogeneity in control variables across different size classes, we run separate regressions for each efficient size class. We find that coefficients of control variables vary notably through subsamples, particularly DIVERSIFICATION. Columns 1-3 (4-6) of Table 6 present results by using TOC (OSC). In the optimal size class, the sensitivity of sales with respect to market demand is large and significant for industrial and financial companies (0.0313 and 0.0391, respectively), whereas it is not significant for family firms. This implies that the owner status is likely to affect firm's performance not only in $C_{-1}$ and $C_{+1}$ but also in the optimal size class $C_{0}$. As the subsamples have a very large number of observations, we run separate regressions for any size class. Again, we find lower sensitivity to demand shocks for family firms in $C_{-1}$ and $C+{ }_{1}$ than other firms. It confirms the existence of some inverted U-shaped effect of family ownership on firm performance. Furthermore, industrial and financial companies outperform family and other owners when sensitivity is measured within the optimal size class, thus making the reactiveness to market demand a non-random aspect of their behaviour. Results are 
similar when OSC is used to identify the optimal size class, even if the difference between the sensitivity in $C_{-1}$ and $C_{+1}$ tends to decrease. ${ }^{7}$

\section{Robustness analysis}

We carried out a large number of tests to check the robustness of our results. First, in addition to different variables (Turnover, Operating Surplus, Number of Firms and Employees) we adopted different criteria to define the optimal size class. We defined changes in the size classes both as a percentage increase or as a change in absolute values between two different points of time. We have set a large number of potential minimum thresholds, both in relative and absolute values, to identify the optimal size class. Second, different time intervals were used to identify optimal size class. We followed a fixed-to-fixed approach (for example, changes in the distribution from 1995 to 2005 for all sectors), variable-to-variable approach (a sliding time interval according to the data availability for each sector), and variable-to-fixed/fixed-tovariable approach (a combination of the previous two methods) in which the time interval is adjusted by changing the initial and final year for each sector. Third, as larger firms in $C_{+1}$ may experience some market power, we addressed this issue in two ways: i) by adding the return on sales (ROS) as an independent variable to control for the potential impact of larger unit profit margins in bigger companies and ii) by repeating the analysis for the subsample of firms with less than 1,000 employees. In both cases, no differences have been observed with respect to previous results. Fourth, we tested the impact of more than three size classes in the size distribution. As Giordano (2003) suggested that six to nine size classes may be a good number of classes for the empirical definition of the optimal class, we repeated all the econometric exercises by using a five-size-class disaggregation (the optimal size class, two smaller-than-optimal and two larger-than-optimal size classes), which is the largest disaggregation allowed by our data. Even if the smallest and the largest size classes often showed insufficient observations or outliers, results obtained from the intermediate size classes largely confirmed previous results.

Finally, we used country dummies to control for different impacts of local markets on firm's sales. In previous estimations, we assumed a single market for the

\footnotetext{
${ }^{7}$ We cannot run unconstrained model using age sub-samples because of the low number of observations in some classes.
} 
countries of our sample. The assumption is acceptable because all countries belong to European Union, but this could not be true. Theoretically, as ATI is a sector-specific index at European single market level, country-specific effects could still affect our results. However, by using country dummies to control for specific country effects, we did not find relevant differences with the empirical estimates reported in Tables 5 and 6.

\section{Conclusion}

We test the hypothesis that firm capability to follow the market demand depends on the gap between actual and optimal firm size and by the identity of the owner. Using survivor technique to identify the optimal size class, we measure how the sensitivity of firm sales to demand shocks changes in response to different owner identities in a panel of 7,459 continental western European firms over the period 1995-2004.

We contribute to the existing literature in two ways. First, we introduce a measure of performance targeted to evidence the entrepreneurial spirit of the company. Using the sensitivity of firm sales to demand trend, we can assess the impact of owner's identity on the ability of the company to seize market opportunities. In contrast to the standard measures of performance (firm growth or profits), this allows us to have a better understanding of the owner identity issue within the agency framework. Second, we distinguish the behaviour of family firms according to their size gap, thus contributing to understand how different family motivations can affect the family firms in comparison to firms belonging to size clusters having a similar probability of adopting a size-adjusting strategy.

Empirical findings confirm our main hypothesis. Estimated results show a nonlinear ability of family businesses to seize market opportunities with respect to the firm size gap. Family businesses are significantly less sensitive to demand changes than other firms, particularly when the actual firm size is larger than optimal. As seizing market opportunities is an inherently risky activity, our explanation relies on the risk aversion of family businesses, which hinders family entrepreneurs to adopt risky decisions targeted to match market demand (Schulze et al., 2003; Shepherd and Zacharakis, 2000; Burkart et al., 2003). In particular, when the size gap is significant, both the trade-off hypothesis ("control for growth") and the "inertia" hypothesis may help to explain the empirical findings. 
As family firms proved to be less sensitive to demand shocks, a straight implication of this result raises concern regarding how a different ownership structure at country level may affect the ability of the economy to react to negative shocks or to gain from upturns in demand. We plan to investigate this issue in our future studies. 


\section{References}

Almeida e Brito J G, John K. Leverage and Growth Opportunities: Risk-Avoidance Induced by Risky Debt. EFMA 2001, available at SSRN: http://ssrn.com/abstract=269580

Angelini P, Generale A. On the evolution of the firms size distribution. American Economic Review 2008;98(1);426-438

Audretsch D. New-firm survival and the technological regime. Review of Economics and Statistics 1991;60(3)

Audretsch D. Innovation and Industry Evolution, MIT Press: Cambridge; 1995

Audretsch D, Yamawaki H 1992. Sub-optimal scale plants and compensating factors differentials in US and Japanese manufacturing. In: Audretsch D, Siegfried J (eds), Empirical studies in Industrial Organisation: Essays in Honor of Leonard Weiss, Kluwer: Boston

Audretsch D, van Leeuwen G, Menkveld B, Thurik R. Market dynamics in the Netherlands: Competition policy and the role of small firms. International Journal of Industrial Organization 2001;19(5);795-821

Balloni V, Cucculelli M. Modelli di impresa e di industria nei contesti di competizione globale: stili organizzativi e rapporti tra imprese nelle aree ad alta intensità industriale. L'Industria 1998;19(2);287-313

Baumol W. Business behaviour, value and growth. McMillan: New York, 1959.

Bergh D D, Ngah-Kiing Lim E. Learning how to restructure: absorptive capacity and improvisational views of restructuring actions and performance. Strategic Management Journal 2008;29;593-616

Bertrand M, Mehta P, Mullainathan S. Ferreting out tunnelling: an application to Indian business groups. Quarterly Journal of Economics 2002;117(1);121-148

Bertrand M, Schoar A. Managing with Style. The Effect of Managers on Firm Policies. Quarterly Journal of Economics 2003;143(4);1169-1208

Bertrand M, Schoar A. The role of family in family firms. Journal of Economic Perspectives 2006;20(2);73-96

Blair R D, Vogel R J. A Survivor Analysis of Commercial Health Insurers. Journal of Business 1978;51(3);521-29

Burkart M, Panunzi F, Shleifer A. Family firms. Journal of Finance 2003;58(5);21672202

Cabral L M B, Mata J. On the Evolution of the Firm Size Distribution: Facts and Theory. American Economic Review 2003;93;1075-90

Demirguc-Kunt A, Maksimovic V. Law, finance and firm growth. Journal of Finance 1998;53(6);2107-2137

Demsetz H, Lehn K. The structure of corporate ownership: Causes and consequences. Journal of Political Economy 1985;93(6);1155-1177 
Faccio M, Lang L. The ultimate ownership of Western European corporations. Journal of Financial Economics 2002;65;365-395

Fama E. Agency problem and the theory of the firm. Journal of Political Economy $1980 ; 88$

Frydman R, Hessel M, Rapaczynski A. Why ownership matters? Columbia Law School Working paper 1998;172

George G, Wiklund J, Zahra S. Ownership and internationalisation of small firms, Journal of Management 2005;31(2);210-233

Geroski P A, Gugler K P. Corporate growth convergence in Europe. CEPR Discussion paper $2001 ; 2838$

Giordano J N. Using the Survivor Technique to Estimate Returns to Scale and Optimum Firm Size. Topics in Economic Analysis \& Policy 2003;3(1);259-281

Goodstein J G, Boeker W B. Turbulence at the top: a new perspective on governance structure changes and strategic change. Academy of Management Journal $1991 ; 34(2)$

Goddard J, Tavakoli M, Wilson J. Determinants of profitability in European manufacturing and services: Evidence from a dynamic panel data. Applied Financial Economics 2005;15;1269-1282

Gomez Mejia L, Haynes K T, Nunez M, Jacobson K, Moyano J. Socio-emotional wealth and business risk in family-controlled firms: evidence from Spanish olive market. Administrative Science Quarterly 2007;52;106-137

Greene W. Econometric analysis. New York: Macmillan; 1997

Grosfeld I, Roland G. Defensive and strategic restructuring in Central European enterprises. Emergo. Journal of Transforming Economies and Societies 1996;3(4)

Hamelin A, Trojman J. Family ownership and growth: The case of French SMEs, Working Papers CEB 07-024.RS 2007, Université Libre de Bruxelles, Solvay Brussels School of Economics and Management, Centre Emile Bernheim (CEB)

Jensen M, Meckling W. Theory of the firm: Managerial behavior, agency costs and ownership structure. Journal of Financial Economics 1976;3(4);305-360

Maury B. Family ownership and firm performance: Empirical evidence from Western European corporations. Journal of Corporate Finance, 2006;12;321-341.

Miller D. The correlates of entrepreneurship in three types of firms. Management Science 1983;27;770-791

Miller D, Le Breton-Miller I, Lester R H, Cannella A A Jr. Are family firms really superior performers? Journal of Corporate Finance 2007;13;829-858

Miller D, Le Breton-Miller I, Scholnick B. Stewardship vs. Stagnation: An Empirical Comparison of Small Family and Non-Family Businesses. Journal of Management Studies 2008;45(1);51-78

Mueller DC. A life cycle theory of the firms. Journal of Industrial Economics 1972;20;199-219 
Pedersen T, Thomsen S. Ownership structure and value of the largest European firms: the importance of owner identity. Journal of Management and Governance $2003 ; 7 ; 27-55$

Sargant F A. The problem of management and the size of the firms: a reply. Economic Journal 1943;44;723-729

Serrasqueiro Z S, Macas Nunes P. Performance and size: empirical evidence from Portuguese SMEs. Small Business Economics 2008;31;197-217

Shepherd D A, Zacharakis A. Structuring family business succession: an analysis of the future leader decision making. Entrepreneurship. Theory and Practice 2000;24(4)

Schulze W S, Lubatkin M H, Dino R N A. Exploring the agency consequences of ownership dispersion among the directors of private family firms. Academy of Management Journal 2003;46(2)

Simon H. Theories of decision making in Economics and Behavioral Science. American Economic Review 1959;49;253

Sonfield M, Lussier R. Firm First generation and subsequent generation family firms: a comparison. Proceedings of the National Conference of the Small Business Institute 2002;153-161

Sraer D, Thesmar D. Performance and Behaviour of Family Firms: Evidence from the French Stock Market. Journal of the European Economic Association 2007;5(4);709-751

Stavrou E, Kassinis G, Filotheou A. Downsizing and stakeholder orientation among the Fortune 500: does family ownership matter? Journal of Business Ethics 2007;72;149-162

Stigler G J. The Economies of Scale. The Journal of Law and Economics 1958;1;54-71

Thomsen S, Pedersen T. Ownership structure and economic performance in the largest European companies. Strategic Management Journal 2000;21;689-705

Verbeek M. Modern econometrics. Wiley: 2000

Villalonga B, Amit R H. How do family ownership, control, and management affect firm value. Journal of Financial Economics 2006;80;385-417

Zahra S A. Entrepreneurial risk taking in family firms. Family Business Review, 2005;18(1); 23-40. 
Table 1a. Descriptive statistics for the total sample and by owner identity

\begin{tabular}{llrrrrrr}
\hline \multirow{2}{*}{ Ownership } & \multicolumn{1}{c}{ Variable } & Mean & St. Dev. & Median & Min & Max & $\begin{array}{r}\text { Number } \\
\text { of firms }\end{array}$ \\
\hline \multirow{5}{*}{ Family Business } & SALES & 25,180 & 66,836 & 17,164 & 292.000 & $1,350,964$ & 777 \\
& ATI & 105.1 & 13.6 & 105.0 & 61.7 & 147.8 & 1,303 \\
& EMPLOYEES & 185.4 & 200.3 & 140 & 20 & 1,802 & 1,355 \\
& AGE & 34.0 & 18.0 & 29 & 10 & 159 & 1,323 \\
& DIVERSIFICATION & 2.811 & 1.112 & 2 & 1 & 7 & 1,355 \\
\hline \multirow{3}{*}{ Industrial } & SALES & 55,486 & 88,739 & 25,384 & 286.999 & $1,596,097$ & 2,431 \\
& ATI & 106.4 & 14.1 & 107.1 & 47.8 & 147.8 & 3,747 \\
& EMPLOYEES & 253.6 & 291.5 & 150 & 20 & 2,000 & 3,862 \\
& AGE & 38.3 & 22.5 & 31 & 10 & 254 & 3,825 \\
& DIVERSIFICATION & 2.639 & 0.998 & 2 & 1 & 12 & 3,862 \\
\hline \multirow{4}{*}{ Compancial } & SALES & 59,347 & 82,713 & 25,649 & 955.999 & $474,720.9$ & 135 \\
& ATI & 106.0 & 14.8 & 107.1 & 64.3 & 147.8 & 139 \\
& EMPLOYEES & 291.0 & 329.1 & 159 & 20 & 1,996 & 143 \\
& AGE & 42.2 & 24.4 & 35 & 14 & 175 & 141 \\
& DIVERSIFICATION & 2.685 & 0.914 & 2 & 1 & 5 & 143 \\
\hline \multirow{5}{*}{ Other Firms* } & SALES & 37,376 & 47,639 & 22,349 & 378 & $570,370.1$ & 1,859 \\
& ATI & 105.9 & 14.1 & 107.1 & 47.8 & 147.8 & 1,866 \\
& EMPLOYEES & 173.4 & 219.6 & 105 & 20 & 1,900 & 2,099 \\
& AGE & 39.3 & 19.2 & 35 & 11 & 201 & 2,080 \\
& DIVERSIFICATION & 2.532 & 1.071 & 2 & 1 & 7 & 2,099 \\
\hline \multirow{5}{*}{ Total } & SALES & 44,588 & 73,951 & 22,789 & 286.999 & $1,596,097$ & 5,202 \\
& ATI & 106.0 & 14.0 & 107.1 & 47.8 & 147.8 & 7,055 \\
& EMPLOYEES & 219.4 & 261.5 & 133 & 20 & 2,000 & 7,459 \\
& AGE & 37.9 & 21.0 & 32 & 10 & 254 & 7,369 \\
& DIVERSIFICATION & 2.641 & 1.043 & 2 & 1 & 12 & 7,459 \\
\hline
\end{tabular}

The table reports descriptive statistics for the total sample by owner identity. Variables description: SALES $=$ Firm's sales in 2004 (x 1.000 Euro); ATI = Annual Turnover Index in 2004 (base year $2000=100$ ). EMPLOYEES = firm's employees in 2003 (number); AGE = firm's age in 2003 (years); DIVERSIFICATION = number of four -digits sectors in which the firm operated in 2004 (number). Ownership classifications are from AMADEUS.

* The residual group of owners includes the following: Foundation, Employees/Managers, Insurance companies, Mutual and Pension Funds, Funds/Trust, Self-owned and Other unnamed shareholders (Source: AMADEUS). 
Table 1b. Firm growth rate by owner identity and firm age

\begin{tabular}{lccc}
\hline \multirow{2}{*}{ Ownership } & \multicolumn{3}{c}{ Firm Age } \\
\cline { 2 - 4 } & All & $<25$ & $>40$ \\
\hline Family Business & 0.0176368 & 0.026937 & 0.0077088 \\
Industrial Company & 0.0112221 & 0.018156 & 0.0063846 \\
Financial Company & 0.0092696 & 0.011792 & 0.0070307 \\
Other Firms * & 0.0114745 & 0.017824 & 0.0073684 \\
\hline Total & 0.0122839 & 0.019736 & 0.0068972 \\
\hline
\end{tabular}

The table reports growth rate of sales for the total sample by owner identity and firm age. Variables description: All = Whole dataset; $<25=$ Subsample of firms under 25 years old; $>40=$ subsample of firms over 40 years old.

* The residual group of owners includes the following: Foundation, Employees/Managers, Insurance companies, Mutual and Pension Funds, Funds/Trust, Self-owned and Other unnamed shareholders (Source: AMADEUS). 
Table 2. Descriptive statistics of the sample by size class

\begin{tabular}{rl|rrrr}
\hline $\begin{array}{c}\text { Size Class } \\
\text { Ranking }\end{array}$ & Variable & \multicolumn{1}{c}{ Turnover } & $\begin{array}{c}\text { Operating } \\
\text { Surplus }\end{array}$ & $\begin{array}{c}\text { Number of } \\
\text { Enterprises }\end{array}$ & Employment \\
\hline \multirow{4}{*}{-1} & SALES & 27,525 & $28,728.28$ & $27,503.48$ & $27,467.75$ \\
& ATI & 107.4 & 108.0 & 103.9 & 106.3 \\
& EMPLOYEES & 106.2 & 107.4 & 95.6 & 102.8 \\
& AGE & 36.7 & 36.8 & 35.2 & 36.1 \\
& DIVERSIFICATION & 2.822 & 2.830 & 2.572 & 2.734 \\
\hline \multirow{4}{*}{0} & SALES & $48,287.13$ & $50,884.52$ & $37,271.23$ & $43,972.29$ \\
& ATI & 108.0 & 107.2 & 106.5 & 108.2 \\
& EMPLOYEES & 229.5 & 230.7 & 170.9 & 211.3 \\
& AGE & 39.6 & 39.3 & 38.4 & 39.1 \\
& DIVERSIFICATION & 2.629 & 2.649 & 2.834 & 2.692 \\
\hline \multirow{4}{*}{ Total } & SALES & $93,988.96$ & $67,624.44$ & $68,107.41$ & $104,843.1$ \\
& ATI & 103.6 & 106.0 & 110.0 & 106.0 \\
& EMPLOYEES & 395.3 & 308.5 & 299.8 & 411.6 \\
& AGE & 39.7 & 39.6 & 40.5 & 42.1 \\
& DIVERSIFICATION & 2.650 & 2.624 & 2.663 & 2.740 \\
\hline \hline \multirow{2}{*}{ SALES } & $45,294.77$ & $45,294.77$ & $45,294.77$ & $45,294.77$ \\
& ATI & 107.1 & 107.1 & 107.1 & 107.1 \\
& EMPLOYEES & 199.5 & 199.5 & 199.5 & 199.5 \\
& AGE & 38.4 & 38.4 & 38.4 & 38.4 \\
& DIVERSIFICATION & 2.714 & 2.714 & 2.714 & 2.714 \\
\hline
\end{tabular}

The table reports descriptive statistics for the total sample by size class. Variables description: SALES $=$ Firm sales in 2004 (x1.000 euro); ATI = Annual Turnover Index in 2004 (base year $2000=100,000$ ). EMPLOYEES $=$ firm employees in 2003 (number); AGE = firm age in 2003 (years); DIVERSIFICATION = number of four-digits sectors in which firms operated in 2004 (number). Ranking indicates the position of firms with respect to efficient size class: $-1=$ lowerthan -optimal size class, $0=$ optimal size class, $+1=$ larger-than-optimal size class. Descriptions (Turnover, Operating surplus, Number of enterprises and Employment) at the beginning of each column indicate the variable used to run the survivor analysis. 
Table 3. Distribution of sectoral $\chi^{2}$ tests on size class identification

\section{Test $\chi^{2} \mathrm{~A}^{*}$.}

Difference of share distribution through size classes

\begin{tabular}{|c|c|c|c|c|c|c|c|c|}
\hline & \multicolumn{4}{|c|}{ ( } & \multicolumn{4}{|c|}{ 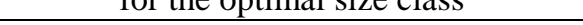 } \\
\hline & Confidence & Freq. & Percent & Cum. & Confidence & Freq. & Percent & Cum. \\
\hline \multirow{7}{*}{ Turnover } & 0.01 & 0 & 0.00 & 0.00 & 0.01 & 0 & 0.00 & 0.00 \\
\hline & 0.05 & 0 & 0.00 & 0.00 & 0.05 & 5 & 0.89 & 0.89 \\
\hline & 0.10 & 0 & 0.00 & 0.00 & 0.10 & 15 & 2.67 & 3.56 \\
\hline & 0.25 & 1 & 0.16 & 0.16 & 0.25 & 106 & 18.86 & 22.42 \\
\hline & 0.50 & 1 & 0.16 & 0.32 & 0.50 & 169 & 30.07 & 52.49 \\
\hline & 1.00 & 618 & 99.68 & 100.00 & 1.00 & 267 & 47.51 & 100.00 \\
\hline & Total & 620 & 100.00 & & Total & 562 & 100.00 & \\
\hline \multirow{7}{*}{$\begin{array}{c}\text { Operating } \\
\text { Surplus }\end{array}$} & 0.01 & 0 & 0.00 & 0.00 & 0.01 & 0 & 0.00 & 0.00 \\
\hline & 0.05 & 0 & 0.00 & 0.00 & 0.05 & 2 & 0.43 & 0.43 \\
\hline & 0.10 & 0 & 0.00 & 0.00 & 0.10 & 6 & 1.28 & 1.71 \\
\hline & 0.25 & 6 & 1.19 & 1.19 & 0.25 & 60 & 12.82 & 14.53 \\
\hline & 0.50 & 7 & 1.38 & 2.57 & 0.50 & 137 & 29.27 & 43.80 \\
\hline & 1.00 & 493 & 97.43 & 100.00 & 1.00 & 263 & 56.20 & 100.00 \\
\hline & Total & 506 & 100.00 & & Total & 468 & 100.00 & \\
\hline
\end{tabular}

The table summarizes the distribution of Chi squared tests for the size class identification. In both tests $\mathrm{A}$ and $\mathrm{B}$, differences are tested under the null hypothesis of invariance of firm size distribution and are repeated for the two variables that are used to identify the optimal size class, i.e. Turnover and Operating surplus. Confidence indicates the probability level to not reject null hypothesis. Freq is the number of sectors in the interval of Confidence, which is the number of sectors with no significant difference over the period. In these sectors, the use of survivor technique is not appropriate.

$*=4$ degrees of freedom. $* *=1$ degree of freedom (see text). 
Table 4. Distribution of firms by Size Class and Ownership in 2004

\begin{tabular}{|c|c|c|c|c|c|c|}
\hline \multicolumn{2}{|c|}{ Size Class } & \multicolumn{5}{|c|}{ Ownership } \\
\hline Variable & Ranking & $\begin{array}{c}\text { Family } \\
\text { Business }\end{array}$ & $\begin{array}{l}\text { Industrial } \\
\text { Company }\end{array}$ & $\begin{array}{l}\text { Financial } \\
\text { Company }\end{array}$ & $\begin{array}{c}\text { Other } \\
\text { Firms* }\end{array}$ & Total \\
\hline \multirow[t]{6}{*}{ Turnover } & -1 & 242 & 664 & 30 & 397 & 1,333 \\
\hline & & $45.75 \%$ & $41.40 \%$ & $37.04 \%$ & $43.48 \%$ & $42.63 \%$ \\
\hline & 0 & 219 & 689 & 45 & 415 & 1,368 \\
\hline & & $41.40 \%$ & $42.96 \%$ & $55.56 \%$ & $45.45 \%$ & $43.75 \%$ \\
\hline & +1 & 68 & 251 & 6 & 101 & 426 \\
\hline & & $12.85 \%$ & $15.65 \%$ & $7.41 \%$ & $11.06 \%$ & $13.62 \%$ \\
\hline \multirow[t]{8}{*}{ Operating Surplus } & -1 & 206 & 622 & 39 & 347 & 1,214 \\
\hline & & $38.94 \%$ & $38.78 \%$ & $48.15 \%$ & $38.01 \%$ & $38.82 \%$ \\
\hline & 0 & 208 & 626 & 35 & 375 & 1,244 \\
\hline & & $39.32 \%$ & $39.03 \%$ & $43.21 \%$ & $41.07 \%$ & $39.78 \%$ \\
\hline & +1 & 115 & 356 & 7 & 191 & 669 \\
\hline & & $21.74 \%$ & $22.19 \%$ & $8.64 \%$ & $20.92 \%$ & $21.39 \%$ \\
\hline & Total & 529 & 1,604 & 81 & 913 & 3,127 \\
\hline & & $100.00 \%$ & $100.00 \%$ & $100.00 \%$ & $100.00 \%$ & $100.00 \%$ \\
\hline
\end{tabular}

The table reports the distribution of firms by owner identity and size class for the two variables used to identify the optimal size class (Turnover and Operating Surplus). The Ownership classification is from AMADEUS. Ranking indicates the position of firms with respect to the efficient size class: -1 $=$ smaller-than-optimal size class, $0=$ optimal size class, and $+1=$ larger-than-optimal size class. Absolute (above) and percentage values (below).

* The residual group of owners includes the following: Foundation, Employees/Managers, Insurance companies, Mutual and Pension Funds, Funds/Trust, Self-owned and Other unnamed shareholders (Source: AMADEUS). 
Table 5a. Sensitivity of sales to market by ownership and three Turnover size classes. Random effect estimations with homogeneous controls over the period 1995-2004.

\begin{tabular}{|c|c|c|c|c|c|c|}
\hline \multirow{2}{*}{ Variables } & \multirow{2}{*}{ Baseline } & \multirow{2}{*}{ Ownership } & Efficient & \multicolumn{3}{|c|}{ Interactive } \\
\hline & & & Size Class & All & Under 25 & Over 40 \\
\hline ATI & $\begin{array}{c}0.689 * * * \\
(0.028)\end{array}$ & $\begin{array}{c}0.692 * * * \\
(0.028)\end{array}$ & $\begin{array}{c}0.421 * * * \\
(0.033)\end{array}$ & $\begin{array}{c}0.423 * * * \\
(0.033)\end{array}$ & $\begin{array}{c}0.341 * * * \\
(0.077)\end{array}$ & $\begin{array}{c}0.316 * * * \\
(0.049)\end{array}$ \\
\hline ATI*Family & & $\begin{array}{c}-0.0725 * * * \\
(0.0033)\end{array}$ & & & & \\
\hline ATI*Industrial & & $\begin{array}{c}0.0134 * * * \\
(0.0024)\end{array}$ & & & & \\
\hline ATI*Financial & & $\begin{array}{c}0.0184 * * * \\
(0.0070)\end{array}$ & & & & \\
\hline ATI*Size class $(-1)$ & & & $\begin{array}{c}-0.0234 * * * \\
(0.0022)\end{array}$ & $\begin{array}{c}-0.0260 * * * \\
(0.0030)\end{array}$ & $\begin{array}{c}-0.0140 * * \\
(0.0057)\end{array}$ & $\begin{array}{c}-0.0210 * * * \\
(0.0052)\end{array}$ \\
\hline ATI* Size class $(+1)$ & & & $\begin{array}{c}0.0398 * * * \\
(0.0031)\end{array}$ & $\begin{array}{c}0.0266 * * * \\
(0.0054)\end{array}$ & $\begin{array}{c}0.0055 \\
(0.0098)\end{array}$ & $\begin{array}{c}0.0417 * * * \\
(0.0091)\end{array}$ \\
\hline ATI $^{*}$ Family $_{-1}$ & & & & $\begin{array}{c}-0.0120 * * * \\
(0.0046)\end{array}$ & $\begin{array}{l}-0.0056 \\
(0.0092)\end{array}$ & $\begin{array}{c}-0.0220 * * \\
(0.0089)\end{array}$ \\
\hline ATI $^{*}$ Family $_{+1}$ & & & & $\begin{array}{c}-0.0286 * * * \\
(0.0095)\end{array}$ & $\begin{array}{l}-0.0243 \\
(0.022)\end{array}$ & $\begin{array}{c}-0.0436 * * * \\
(0.013)\end{array}$ \\
\hline $\mathrm{ATI}^{*}$ Industrial $_{-1}$ & & & & $\begin{array}{c}0.0088 * * * \\
(0.0034)\end{array}$ & $\begin{array}{c}0.0057 \\
(0.0065)\end{array}$ & $\begin{array}{l}-0.0103^{*} \\
(0.0062)\end{array}$ \\
\hline ATI*Industrial $_{+1}$ & & & & $\begin{array}{c}0.0270 * * * \\
(0.0063)\end{array}$ & $\begin{array}{c}0.0334 * * * \\
(0.011)\end{array}$ & $\begin{array}{l}0.0086 \\
(0.011)\end{array}$ \\
\hline ATI*Financial $_{-1}$ & & & & $\begin{array}{c}0.0036 \\
(0.0098)\end{array}$ & $\begin{array}{c}-0.0049 \\
(0.018)\end{array}$ & $\begin{array}{l}-0.0113 \\
(0.015)\end{array}$ \\
\hline ATI*Financial $_{+1}$ & & & & $\begin{array}{c}0.0389 * \\
(0.021)\end{array}$ & $\begin{array}{l}0.107 * \\
(0.060)\end{array}$ & $\begin{array}{l}0.0042 \\
(0.026)\end{array}$ \\
\hline $\log \left(\right.$ EMPLOYEE $\left._{\mathrm{t}-1}\right)$ & $\begin{array}{c}0.188 * * * \\
(0.0054)\end{array}$ & $\begin{array}{c}0.189 * * * \\
(0.0054)\end{array}$ & $\begin{array}{c}0.192 * * * \\
(0.0063)\end{array}$ & $\begin{array}{c}0.190 * * * \\
(0.0063)\end{array}$ & $\begin{array}{c}0.389 * * * \\
(0.016)\end{array}$ & $\begin{array}{c}0.109 * * * \\
(0.0090)\end{array}$ \\
\hline $\log \left(\mathrm{AGE}_{\mathrm{t}-1}\right)$ & $\begin{array}{c}0.121 * * * \\
(0.017)\end{array}$ & $\begin{array}{c}0.104 * * * \\
(0.016)\end{array}$ & $\begin{array}{c}0.0686 * * * \\
(0.018)\end{array}$ & $\begin{array}{c}0.0751 * * * \\
(0.018)\end{array}$ & $\begin{array}{l}0.0247 \\
(0.079)\end{array}$ & $\begin{array}{l}0.0211 \\
(0.041)\end{array}$ \\
\hline DIVERSIFICATION & $\begin{array}{c}-0.148 * * * \\
(0.013)\end{array}$ & $\begin{array}{c}-0.117 * * * \\
(0.012)\end{array}$ & $\begin{array}{r}0.00627 \\
(0.012)\end{array}$ & $\begin{array}{c}0.00904 \\
(0.012)\end{array}$ & $\begin{array}{l}0.0346 \\
(0.023)\end{array}$ & $\begin{array}{c}-0.00676 \\
(0.019)\end{array}$ \\
\hline Constant & $\begin{array}{c}1.019 * * * \\
(0.32)\end{array}$ & $\begin{array}{c}1.008 * * * \\
(0.32)\end{array}$ & $\begin{array}{c}3.744 * * * \\
(0.38)\end{array}$ & $\begin{array}{c}3.710 * * * \\
(0.38)\end{array}$ & $\begin{array}{c}3.727 * * * \\
(0.93)\end{array}$ & $\begin{array}{c}6.471 * * * \\
(0.74)\end{array}$ \\
\hline Year Dummies & Yes & Yes & Yes & Yes & Yes & Yes \\
\hline Obs. & 44523 & 44523 & 22204 & 22204 & 6689 & 7270 \\
\hline Number of Firms & 5572 & 5572 & 2633 & 2633 & 1199 & 1103 \\
\hline $\mathrm{R} 2$ & 0.197 & 0.238 & 0.338 & 0.347 & 0.439 & 0.324 \\
\hline F Test & 6972 & 7922 & 8802 & 8906 & 3150 & 2451 \\
\hline Prob $>$ F & 0 & 0 & 0 & 0 & 0 & 0 \\
\hline
\end{tabular}

The table reports the estimates of Equation 1. The dependent variable is sales (log). Estimation method: random effect with cluster correction at firm level and robust standard errors. ATI = Annual Turnover Index. Size class identified through Turnover. Size class: -1 indicates firms with a size smaller than the optimal one; +1 subscript indicates firms with a size larger than the optimal one. Robust standard errors in parentheses: $* * * \mathrm{p}<0.01, * * \mathrm{p}<0.05, * \mathrm{p}<0.1$ 
Table 5b. Sensitivity of sales to market by ownership and three Operating Surplus size classes. Random effect estimations with homogeneous controls over the period 1995-2004.

\begin{tabular}{|c|c|c|c|c|c|c|}
\hline \multirow{2}{*}{ Variables } & \multirow{2}{*}{ Baseline } & \multirow{2}{*}{ Ownership } & Efficient & \multicolumn{3}{|c|}{ Interactive } \\
\hline & & & Size Class & All & Under 25 & Over 40 \\
\hline ATI & $\begin{array}{c}0.689 * * * \\
(0.028)\end{array}$ & $\begin{array}{c}0.692 * * * \\
(0.028)\end{array}$ & $\begin{array}{c}0.410 * * * \\
(0.033)\end{array}$ & $\begin{array}{c}0.413 * * * \\
(0.033)\end{array}$ & $\begin{array}{c}0.318 * * * \\
(0.077)\end{array}$ & $\begin{array}{c}0.312 * * * \\
(0.049)\end{array}$ \\
\hline ATI*Family & & $\begin{array}{c}-0.0725 * * * \\
(0.0033)\end{array}$ & & & & \\
\hline ATI*Industrial & & $\begin{array}{c}0.0134 * * * \\
(0.0024)\end{array}$ & & & & \\
\hline ATI*Financial & & $\begin{array}{c}0.0184 * * * \\
(0.0070)\end{array}$ & & & & \\
\hline ATI*Size class $(-1)$ & & & $\begin{array}{c}-0.0216 * * * \\
(0.0023)\end{array}$ & $\begin{array}{c}-0.0232 * * * \\
(0.0032)\end{array}$ & $\begin{array}{c}-0.00686 \\
(0.0060)\end{array}$ & $\begin{array}{c}-0.0255^{* * *} \\
(0.0056)\end{array}$ \\
\hline ATI*Size class $(+1)$ & & & $\begin{array}{c}0.0145^{* * * *} \\
(0.0028)\end{array}$ & $\begin{array}{l}-0.00162 \\
(0.0041)\end{array}$ & $\begin{array}{l}-0.00474 \\
(0.0077)\end{array}$ & $\begin{array}{l}0.0121 * \\
(0.0070)\end{array}$ \\
\hline ATI $^{*}$ Family $_{-1}$ & & & & $\begin{array}{c}-0.0139 * * * \\
(0.0050)\end{array}$ & $\begin{array}{l}-0.0124 \\
(0.0095)\end{array}$ & $\begin{array}{c}-0.0210 * * \\
(0.0092)\end{array}$ \\
\hline ATI $^{*}$ Family $_{+1}$ & & & & $\begin{array}{c}-0.0177 * * \\
(0.0073)\end{array}$ & $\begin{array}{l}-0.0238 \\
(0.015)\end{array}$ & $\begin{array}{c}-0.0190 * \\
(0.011)\end{array}$ \\
\hline ATI*Industrial $_{-1}$ & & & & $\begin{array}{c}0.0073 * * \\
(0.0036)\end{array}$ & $\begin{array}{c}0.000319 \\
(0.0067)\end{array}$ & $\begin{array}{l}-0.00807 \\
(0.0066)\end{array}$ \\
\hline ATI*Industrial $_{+1}$ & & & & $\begin{array}{c}0.0353 * * * \\
(0.0049)\end{array}$ & $\begin{array}{c}0.0272 * * * \\
(0.0091)\end{array}$ & $\begin{array}{c}0.0176 * * \\
(0.0085)\end{array}$ \\
\hline ATI*Financial $_{-1}$ & & & & $\begin{array}{l}-0.0051 \\
(0.0088)\end{array}$ & $\begin{array}{l}-0.0173 \\
(0.015)\end{array}$ & $\begin{array}{c}-0.0176 \\
(0.014)\end{array}$ \\
\hline ATI*Financial $_{+1}$ & & & & $\begin{array}{c}0.0478 * * \\
(0.020)\end{array}$ & $\begin{array}{c}0.0702 * \\
(0.037)\end{array}$ & $\begin{array}{c}0.00679 \\
(0.028)\end{array}$ \\
\hline $\log \left(\right.$ EMPLOYEE $\left._{\mathrm{t}-1}\right)$ & $\begin{array}{c}0.188 * * * \\
(0.0054)\end{array}$ & $\begin{array}{c}0.189 * * * \\
(0.0054)\end{array}$ & $\begin{array}{c}0.201 * * * \\
(0.0063)\end{array}$ & $\begin{array}{c}0.198 * * * \\
(0.0063)\end{array}$ & $\begin{array}{c}0.399 * * * \\
(0.016)\end{array}$ & $\begin{array}{c}0.112 * * * \\
(0.0090)\end{array}$ \\
\hline $\log \left(\mathrm{AGE}_{\mathrm{t}-1}\right)$ & $\begin{array}{c}0.121 * * * \\
(0.017)\end{array}$ & $\begin{array}{c}0.104 * * * \\
(0.016)\end{array}$ & $\begin{array}{c}0.0613 * * * \\
(0.018)\end{array}$ & $\begin{array}{c}0.0681 * * * \\
(0.018)\end{array}$ & $\begin{array}{l}0.0101 \\
(0.079)\end{array}$ & $\begin{array}{l}0.0123 \\
(0.041)\end{array}$ \\
\hline DIVERSIFICATION & $\begin{array}{c}-0.148 * * * \\
(0.013)\end{array}$ & $\begin{array}{c}-0.117 * * * \\
(0.012)\end{array}$ & $\begin{array}{c}0.00320 \\
(0.012)\end{array}$ & $\begin{array}{l}0.0103 \\
(0.012)\end{array}$ & $\begin{array}{l}0.0309 \\
(0.023)\end{array}$ & $\begin{array}{c}0.00216 \\
(0.020)\end{array}$ \\
\hline Constant & $\begin{array}{c}1.019 * * * \\
(0.32)\end{array}$ & $\begin{array}{c}1.008 * * * \\
(0.32)\end{array}$ & $\begin{array}{c}3.872 * * * \\
(0.38)\end{array}$ & $\begin{array}{c}3.818 * * * \\
(0.38)\end{array}$ & $\begin{array}{c}4.040 * * * \\
(0.93)\end{array}$ & $\begin{array}{c}6.521^{* * * *} \\
(0.75)\end{array}$ \\
\hline Year Dummies & Yes & Yes & Yes & Yes & Yes & Yes \\
\hline Obs. & 44523 & 44523 & 22204 & 22204 & 6689 & 7270 \\
\hline Number of Firms & 5572 & 5572 & 2633 & 2633 & 1199 & 1103 \\
\hline $\mathrm{R} 2$ & 0.197 & 0.238 & 0.317 & 0.327 & 0.431 & 0.294 \\
\hline F Test & 6972 & 7922 & 8500 & 8650 & 3115 & 2385 \\
\hline Prob $>$ F & 0 & 0 & 0 & 0 & 0 & 0 \\
\hline
\end{tabular}

The table reports the estimates of Equation 1. The dependent variable is sales (log). Estimation method: random effect with cluster correction at firm level and robust standard errors. ATI = Annual Turnover Index. Size class identified through Operating Surplus. Size class: -1 indicates firms with a size smaller than the optimal one; +1 subscript indicates firms with a size larger than the optimal one. Robust standard errors in parentheses: *** $\mathrm{p}<0.01$, ** $\mathrm{p}<0.05, * \mathrm{p}<0.1$ 
Table 6. Sensitivity of sales to market by ownership for each of three Turnover size classes and three Operating Surplus size classes. Random effect estimations with heterogeneous controls.

\begin{tabular}{|c|c|c|c|c|c|c|}
\hline \multirow[t]{2}{*}{ Variables } & \multicolumn{3}{|c|}{$\begin{array}{l}\text { Efficient Size Class } \\
\text { on Turnover }\end{array}$} & \multicolumn{3}{|c|}{$\begin{array}{l}\text { Efficient Size Class } \\
\text { on Operating Surplus }\end{array}$} \\
\hline & -1 & 0 & +1 & -1 & 0 & +1 \\
\hline ATI & $\begin{array}{c}0.482 * * * \\
(0.080)\end{array}$ & $\begin{array}{c}0.420 * * * \\
(0.078)\end{array}$ & $\begin{array}{c}0.292 * * * \\
(0.097)\end{array}$ & $\begin{array}{c}0.357 * * * \\
(0.084)\end{array}$ & $\begin{array}{c}0.440 * * * \\
(0.079)\end{array}$ & $\begin{array}{c}0.365^{* * *} \\
(0.093)\end{array}$ \\
\hline ATI*Family & $\begin{array}{c}-0.0119 * * * \\
(0.0039)\end{array}$ & $\begin{array}{l}0.00651 \\
(0.0050)\end{array}$ & $\begin{array}{c}-0.0316^{* * * *} \\
(0.010)\end{array}$ & $\begin{array}{c}-0.0142 * * * \\
(0.0041)\end{array}$ & $\begin{array}{l}0.00790 \\
(0.0049)\end{array}$ & $\begin{array}{c}-0.0190 * * \\
(0.0084)\end{array}$ \\
\hline ATI*Industrial & $\begin{array}{c}0.00954 * * * \\
(0.0032)\end{array}$ & $\begin{array}{c}0.0313 * * * \\
(0.0040)\end{array}$ & $\begin{array}{l}0.0179 * * \\
(0.0079)\end{array}$ & $\begin{array}{l}0.00692 * \\
(0.0035)\end{array}$ & $\begin{array}{c}0.0321 * * * \\
(0.0041)\end{array}$ & $\begin{array}{c}0.0220 * * * \\
(0.0061)\end{array}$ \\
\hline ATI*Financial & $\begin{array}{c}0.00436 \\
(0.011)\end{array}$ & $\begin{array}{c}0.0391 * * * \\
(0.012)\end{array}$ & $\begin{array}{l}0.0169 \\
(0.022)\end{array}$ & $\begin{array}{c}-0.000454 \\
(0.0086)\end{array}$ & $\begin{array}{c}0.0540 * * * \\
(0.015)\end{array}$ & $\begin{array}{l}0.0299 \\
(0.021)\end{array}$ \\
\hline $\log \left(\right.$ EMPLOYEE $\left._{\mathrm{t}-1}\right)$ & $\begin{array}{c}0.139 * * * \\
(0.018)\end{array}$ & $\begin{array}{c}0.226 * * * \\
(0.018)\end{array}$ & $\begin{array}{c}0.279 * * * \\
(0.029)\end{array}$ & $\begin{array}{c}0.151 * * * \\
(0.017)\end{array}$ & $\begin{array}{c}0.224 * * * \\
(0.020)\end{array}$ & $\begin{array}{c}0.236 * * * \\
(0.024)\end{array}$ \\
\hline $\log \left(\mathrm{AGE}_{\mathrm{t}-1}\right)$ & $\begin{array}{c}0.107 * * * \\
(0.037)\end{array}$ & $\begin{array}{c}0.0770 * * \\
(0.039)\end{array}$ & $\begin{array}{l}0.0715 \\
(0.066)\end{array}$ & $\begin{array}{c}0.0833 * * \\
(0.041)\end{array}$ & $\begin{array}{c}0.102 * * * * \\
(0.037)\end{array}$ & $\begin{array}{l}0.0316 \\
(0.054)\end{array}$ \\
\hline DIVERSIFICATION & $\begin{array}{c}0.0368 * * \\
(0.018)\end{array}$ & $\begin{array}{c}0.00834 \\
(0.023)\end{array}$ & $\begin{array}{c}-0.0835^{*} \\
(0.048)\end{array}$ & $\begin{array}{c}0.0413 * * \\
(0.017)\end{array}$ & $\begin{array}{c}-0.0136 \\
(0.026)\end{array}$ & $\begin{array}{l}-0.0422 \\
(0.039)\end{array}$ \\
\hline Constant & $\begin{array}{c}2.690 * * * \\
(0.93)\end{array}$ & $\begin{array}{c}3.376 * * * \\
(0.89)\end{array}$ & $\begin{array}{l}5.579 * * * \\
(1.20)\end{array}$ & $\begin{array}{c}4.101 * * * * \\
(0.98)\end{array}$ & $\begin{array}{c}3.106 * * * \\
(0.89)\end{array}$ & $\begin{array}{c}4.666^{* * * *} \\
(1.11)\end{array}$ \\
\hline Year Dummies & Yes & Yes & Yes & Yes & Yes & Yes \\
\hline Obs. & & & 3271 & 7343 & 8439 & 5287 \\
\hline Number of Firms & & 1030 & 401 & 899 & 973 & 619 \\
\hline R2 & 0.206 & 0.354 & 0.415 & 0.223 & 0.354 & 0.362 \\
\hline F Test & 1204 & 1670 & 442.4 & 1216 & 1495 & 675.0 \\
\hline Prob $>$ F & 0 & 0 & 0 & 0 & 0 & 0 \\
\hline
\end{tabular}

The table reports the estimated results of Equation 1) by efficient size class. Controls are homogeneous within each efficient size class but can differ across them. Estimation method: random effect with cluster correction at firm level. Efficient size class is -1 for firms with size smaller than the optimal one, 0 for firms in the optimal size class, and +1 for firms with size larger than optimal one. Robust standard errors in parentheses: *** $\mathrm{p}<0.01, * * \mathrm{p}<0.05,{ }^{*} \mathrm{p}<0.1$ 
Figure 1 - Relative share of firms in each size class according to owner identity.

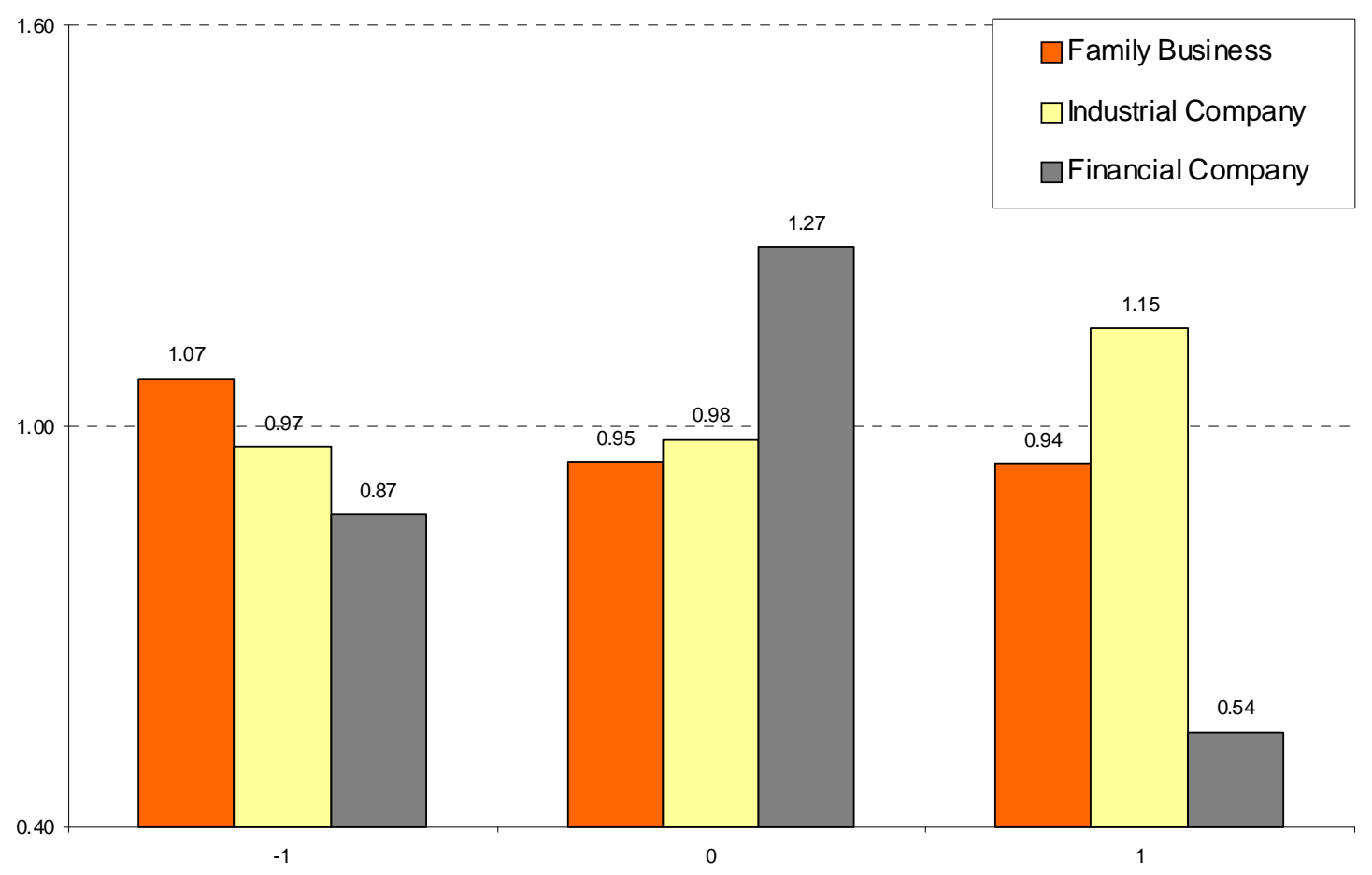

Legend: The histograms show the ratio $I=S_{s, r} / S_{s}$ where $S_{s, r}$ is the share of owner r (family, industrial, financial) in each size class s $(-1=$ smaller-than-optimal size class; $0=$ optimal size class; and $+1=$ larger-than-optimal size class). 


\section{APPENDIX - AMADEUS BVD INDEPENDENCE INDICATOR.}

As the family firm definition is crucial in ownership structure analyses, we have chosen to rely on the BvDEP independence indicator for the ultimate owner identification.

To assist users in identifying independent companies, BvDEP has created an Independence Indicator to characterize the degree of independence of a company with regard to its shareholders. The BvDEP Independence Indicators are noted as A, B, C, D, and U.

Indicator A is attached to any company with known recorded shareholders, none of which having more than $25 \%$ of direct or total ownership. This indicator is further qualified as A+, A, or A- depending on the number of identified shareholders (6 or more, 4-5 or 1-3). BvDEP also gives an A notation to a company that is mentioned by a source (Annual Report, Private Communication or Information Provider) as being the Ultimate Owner of another company, even when its shareholders are not mentioned. A companies are called "Independent companies".

Indicator B is attached to any company with a known recorded shareholder, none of which with an ownership percentage (direct, total or calculated total) over $50 \%$, but having one or more shareholders with an ownership percentage above $25 \%$. Also, this indicator is further qualified as $\mathrm{B}+, \mathrm{B}$, and $\mathrm{B}-$ according to the same criteria relating to the number of recorded shareholders as for indicator $\mathrm{A}$.

Indicator $\mathrm{C}$ is attached to any company with a recorded shareholder with a total or a calculated total ownership over 50\%. The qualification $\mathrm{C}+$ is attributed to $\mathrm{C}$ companies in which the summation of direct ownership percentage (all categories of shareholders included) is $50.01 \%$ or higher. The $\mathbf{C}$ indicator is also given to a company when a source indicates that the company has an ultimate owner, even though its percentage of ownership is unknown.

Indicator $\mathrm{D}$ is allocated to any company with a recorded shareholder with a direct ownership of over 50\%. Indicator $\mathrm{U}$ is allocated to companies that do not fall into the previous classification.

\section{Ultimate Owner Identification}

To define an Ultimate Owner, BvDEP analyzes the shareholding structure of a company having a BvDEP Independence Indicator different from A+, A, or A- (which means that the company is independent and consequently has no Ultimate Owner). It looks for the shareholder with the highest direct or total \% of ownership. If this shareholder is independent, it is defined as the Ultimate Owner of the subject company. If the highest shareholder is not independent, the same process is repeated until BvDEP finds an Ultimate Owner. Each entity at both ends of a link shareholder or subsidiary - is given a "type" according to the following classification:

- Bank

- Financial company

- Insurance company

- Industrial company

- Mutual and pension fund

- Foundation \& Research institute

- Public authorities, States, Governments

- Individuals or families 
- Employees/managers/directors

- Self ownership

- Private equity

- Public

- Unnamed private shareholders

- Other unnamed shareholders aggregated

The last three categories (Public; Unnamed private shareholders, aggregated; Other unnamed shareholders, aggregated) are considered as unable to exert, as such, control over a company. The shareholder information is gathered from several possible sources, including Annual Reports or privately written communications addressed by the company to BvDEP. 